\title{
Investigating the Relationship between Effective Communication of Spouse and Father - Child Relationship (Test Pattern Causes to Education Parents)
}

\author{
Robabeh Ataeifar ${ }^{1}$, Sholeh Amiri ${ }^{2}$ \& Mohammad Ali Nadi ${ }^{3}$ \\ ${ }^{1}$ Department of Educational Psychology, Khorasgan Branch, Islamic Azad University, Isfahan, Iran \\ ${ }^{2}$ Department of Psychology, Isfahan Branch, Isfahan University, Isfahan, Iran \\ ${ }^{3}$ Department of Psychology, Khorasgan Branch, Islamic Azad University, Isfahan, Iran \\ Correspondence: Robabeh Ataeifar, Department of educational Psychology, Khorasgan Branch, Islamic Azad \\ University, Isfahan, Iran. E-mail: esfehani.mohamad3@gmail.com
}

Received: August 18, 2015 Accepted: September 25, 2015 Online Published: June 28, 2016

doi:10.5539/ies.v9n7p98 URL: http://dx.doi.org/10.5539/ies.v9n7p98

\begin{abstract}
This research is targeted with the plan of father-child model or effective relationship mediating of spouses or investigating attachment style, personality traits, communication skills and spouses' sexual satisfaction. Based on this 260 people (father and child) were selected through random sampling method based on share. Participants were tested by relationship between spouses' model questionnaire, adults' attachment style, and communication skill, five factors of personality, sexual satisfaction and father-child relationship. The relationship of attachment style, personality traits, communication skills and sexual satisfaction of spouses or the effective relationship of spouses and father-child are clarified through performing structural equation model for test that proposed model was appropriately fitted and father-child relationship is explained and predicted through variables of attachment style, personality traits , communication skills, spouses' sexual satisfaction and mediating variable of spouses' effective relationship. A positive and significant relationship related to spouses' relationship among men accountability, compatibility and communication skills in spousal relationship and a negative and significant relationship is obtained among neuroticism and men avoidant attachment in spousal relationship and there is also positive significant relationship related to father-child relationship among compatibility and negative significant relationship among anxiety attachment and neuroticism of father is obtained in father-child relationship. it is recommended that for improving family members' relationship, the role and effect kind of effective factors on spouses' relationship and father-child relationship be paid attention and based on proposed model a modification pattern for present defects in marital and parental context can be suggested.
\end{abstract}

Keywords: effective relationship of spouses, father-child relationship, attachment style, communication skill, personality traits, sexual satisfaction

\section{Introduction}

Family is considered as the first social environment that a child step in and the first relationship in child's communication world is father-child one. Feelings of love, intimacy and security are directly rooted in these communications (Carnes-Holt, 2012). One of important helpful elements for creating healthy environment in family is improving the interactions of father-child. The lack of communication with parents in children's life will lead to weaker and more superficial father-child interactions and this issue to turn out causes complicated problems in child's future (Runcan, 2012). According to systematic theory of Bronphen Burner, marital relationship forms a part of micro system (the closest environmental layer to child). Therefor it either affect performance and child's growth directly or father-child relationship indirectly. So satisfactory marital relationship makes family's good performance foundation, facilitates effective parenting and causes the ability of compatibility and adoption in children (O’Leary \& Vidair, 2005).

According to most of experts in marriage subject, this phenomenon needs an efficient and effective communication (Karahan, 2007) because inefficient communication patterns cause that important issues of common life remain unsolved and become the repetitive conflict resource among spouses (Zhang, 2007). Various models and theories explain couples' communication models that among them communication pattern of 
Christensen and Sullaway (1984) is reviewed. They have introduced three models of mutual constructive communication (effective relationship model), mutual avoidance communication and mutual demand/ withdraw communication (ineffective relationship model). Mutual constructive communication is a model where spouses try to discuss problems which are created during communication for them, express their feelings toward each other and find a solution for their problem (Sanford, 2010). Mutual avoidance communication is a model where one of spouses tries to change or vary the discussion and the other one avoid interacting with spouse (Garman, 2008).

The roots of investigating marital relationships refer to late 1960s. After 1971, more than seventy studies were done about spouses' relationships including 40 quantitative studies and 49 qualitative studies (Jakubowski, Mime, Brunner, \& Mile, 2004).

Generally in models that we have currently in 2015 these statistics have been doubled. In the first level there is mental analysis and characteristics approach that emphasize the role of intrapersonal factors and in second level cognitive behavioral therapy perspective is discussed that most emphasizes on interpersonal factors of spouses' relationships.

Family and couple therapy experts have been always looking for perceiving the antecedent and predictive factors of marital relationship's quality and since the relationship of spouses similar to many phenomena is multi-dimensions and many factors are effective on its creation, in this study, the relationship of attachment style, personality traits, communication skills, sexual satisfaction of spouses in spouses' communication and parenting will be investigated.

Marital life begins with joining two characters to each other and each one of couples' personality traits are significantly effective on the rate of self-satisfaction and also their spouse-satisfaction from marital life (Santayana, 2007). One of the most important and influential models in investigating personality traits is five factors model. Five strong factors of personality which are considered as important predictors of interpersonal relationships are neuroticism, extroversion, agreeableness, openness to experience and conscientiousness (Parvin \& John, 2002, translated by Kadivar \& Javadi). People with low levels of neuroticism have emotional stability but people with high levels of neuroticism can't control their emotions appropriately and some of them are nervous, sensitive and worried. Extroverted people are often adventurous, social and talkative while introverted people are taciturn and shy. People with high levels of openness to experience often have wide interests and tend to gain new skills. The trait of agreeableness is identified by kindness, empathy, warmness and sense of cooperation. Incompatible people have weak friendly relationship. Conscientious people have work ethic and discipline and tend to finish works (Hox, 2012 quoted by Tale-pasand \& Shahbazi, 2015). Generally the researches show the existence of relationship of agreeableness, conscientiousness, emotional stability, extroversion and openness with communication satisfaction in spouses (Heller, Watson, \& Hies, 2004; Dyrenforth, Kashy, Donnellan, \& Lucas, 2010; Malouff, Thorsteinsson, Schutte, Bhullar, \& Rooke, 2010; Decuypter, De Bolle, \& De Fruyt, 2012). The most of researches show that avoidance communication model and demand/withraw communication can be seen in neuroticism (Caughlin, Huston, \& Houts, 2000; Donnellane, Conger, \& Bryant, 2004). Researches have shown the relationship between mutual constructive communication with conscientiousness ((Donnellane et al., 2004; Engel, Olson, \& Patrick, 2002), openness (Buss, 1991; Donnellane et al., 2004), agreeableness (Graziano, Jensen-Campbell, \& Hair, 1996; Donnellane et al., 2004) and extroversion (Taraban, S. Hendrick, \& C. Hendrick, 1998; Watson, Hubbard, \& wise, 2000). In investigating the trait of neuroticism, Coglin et al 2000 in a 13 year study concluded that these people express more negative emotions than others and through this help forming negative interactional models in marital relationships. Targeted efforts to maintain stability in marital relationship (Jarvis, 2006), avoiding to show violent behaviors and Inhibiting impulses in marital relationship (Kourdek, 1993) are more seen in conscientious people. On the other hand Rouhner (2007) believes that effective mechanisms on parents' personality affect their receptivity and rejection toward their children. Parents who show higher levels of agreeableness and extroversion and also lower levels of neuroticism, have warmer and structured parenting. These parents have more positive interactions and are responsible enough (Smith, Spinrad, Eisenberg, Payne, Gaertner, \& Maxon, 2007).

Attachment style is one of development-personality structures and an effective factor in interpersonal interactions that is formed as the result of individual's relationships with attachment characters (parents, peers and spouse) and has an important role on marital life relationship and performance and forming adult communication models (Bowlby, 1969; Koepke \& Denissen, 2012). Hazan, Shaver, and Bradshaw (1988) in their studies with discussing emotional love, emphasized attachment process continuation in adulthood and investigated the formation of the three modes of communication of secure attachment, avoidant attachment and anxious attachment which are equal with three main methods of attachment in childhood. The adults' attachment 
theory (Fraley \& Shave, 2000; Milkulincer \& Shaver, 2003, 2007) is in fact the expansion of Bowlby and Einsource attachment theory and explains individual differences in terms of cognition, emotion and behavior that happen in the close relationship context of adult. This theory provides a suitable framework for better understanding of marital relationships (Crowleyh, 2006; Kimberly \& Baker, 2008). Some studies have investigated the comparison of spouses' attachment styles with marital relationships and their results have shown that secure, positive and insecure attachment have negative correlation with satisfaction in marital relationship (Simpson, 1990; Banes, 2004; Keskin, 2008; Nilforooshan, Ahmadi, Fatehizadeh, Abedi, \& Ghasemi, 2014). Studies have shown that people with secure internal practical model have low avoidance in relationships and more involvement in couple relationship (Hollist \& Miller, 2005). These people are warmer, responsible and more involved parents (Ward \& Carlson, 1995). According to attachment theory (Bowlby, 1969, 1980; Cassidy \& Shaver, 2008) people who have secure attachment style, adjust their emotions more in their relationship with their children. In return people with insecure attachment style, show destructive patterns of conflict and the lack of negotiations in their conversations (Feeney, Noller, \& Callan ,1994). Most of people with anxious style are in doubt about their value as a spouse and blame themselves for lack of their spouses' responsibility (Bogaerts, Dallder, Knnap, Kunst, \& Buschman, 2008) and people with avoidance attachment style claim that they don't need close relationships and tend to avoid intimacy (Kardatzke, 2009; Ozmen \& Atik, 2010). On the other hand people with anxious attachment style, give contradictory and unreliable and invalid answers to their children's stresses in their parenting communication (Milkulincer \& Shaver, 2003) and people with avoidance attachment style give compatible but negative answers to child (cold, non-intimate and angrily) and actively express negative emotions and exclusion of child toward negative not positive child's expressions (Rholes, Simpson, Blakely, Lanigan, \& Allen, 1997). In investigating the relationships of spouses, communicational skills are such important skills that are known as the maintenance of satisfactory relationships between spouses (Casten, 2004).

Communication skills are special abilities that help people to act sufficiently in messages which give to the other person and create positive and joyful emotions in opposite side (Kareny \& Bradbury, 2000). These skills include perceiving verbal and non-varbal messages skill, regulation of emotions, listening, insight into the process of communication and assertiveness in communication (Hossien, Chari, \& Fadakar, 2005). Problematic couples show lower communication skills than non-troubled couple and use different kinds of negative and non-effective patterns in expressing thoughts and emotions, listening skills and solving problem (Walsh, 1998). Runcan, Constantineanu, Iclics, and Popa (2012) also have shown in their studies that parents who gained high score in variables of father-child interaction, have more communication skills such as preferring to talk with their children without advising, not saying the things which are bothering, listening to what a child says carefully and encourage the child to talk and express emotions. Sexual satisfaction is considered as the other important indicators of successful marriage and family health and considering the rate of couples' sexual satisfaction, the rate of spouse's interactions can be identified (Barrientos, 2006). Sexual satisfaction refers to the rate of each person's pleasure or joy from sexual relationship (Harvey, Weuzel, \& Sprecher, 2005). An effective relationship can promote sexual stimulation and is needed for beginning or refusing sex (Spercher \& McKinney, 1993). Researches also have shown the relationship between sexual satisfactions with satisfaction from spouses' relationship (Barrientos, 2006). Dissatisfaction from sexual relationship will lead to deep conflicts in spouses' relationships (D. Olson, S. Olson, \& Larson, 2008, translated by Darini \& Navabinejad, 2012) and conflicts between spouses (Moovahed \& Azizi, 2013). On the other hand, either for men or women sexual satisfaction has significant relationship with the level of family performance (Greeff \& Malherbe, 2001). High sexual satisfaction leads to better relationship with children and family (Ji \& Norling, 2004).

Most of done researches in spouses' relationships and father-child relationship are often a kind of empirical researches and hypothesis processing and effective factors and correlation of these factors are investigated separately in spouses' relationship and father-child relationship. Models and empirical theories that explain spouses' relationship appropriately based on the basic elements of personal and interpersonal are still a little paid attention. Therefor this research seeks to investigate the relationship of some factors of attachment style, communication skills, personality traits and sexual satisfaction of spouses with each other on spouses' relationships and father-child relationship in a form of a model. This investigation can answer a part of important questions in the field of spouses' relationship and father-child relationship that lead to reduction of conflicts and problems and improving the increase of satisfaction in marital relationships and following that, better relationship of parents with their children in order to maintain the family and as a result society's health and mental health promotion.

Hypotheses:

1) The relationship between personality traits, communication skills, attachment style and spouses' sexual 
satisfaction with spouses' relationship and with father-child relationship based on structural equation modeling, is ideally significant.

2) There is a significant relationship between personality traits, communication skills, attachment style and spouses' sexual satisfaction with mother-child relationship with spouses' effective relationship mediating. Considering what have been said and summarizing the research literature, below hypothetical model is obtained.

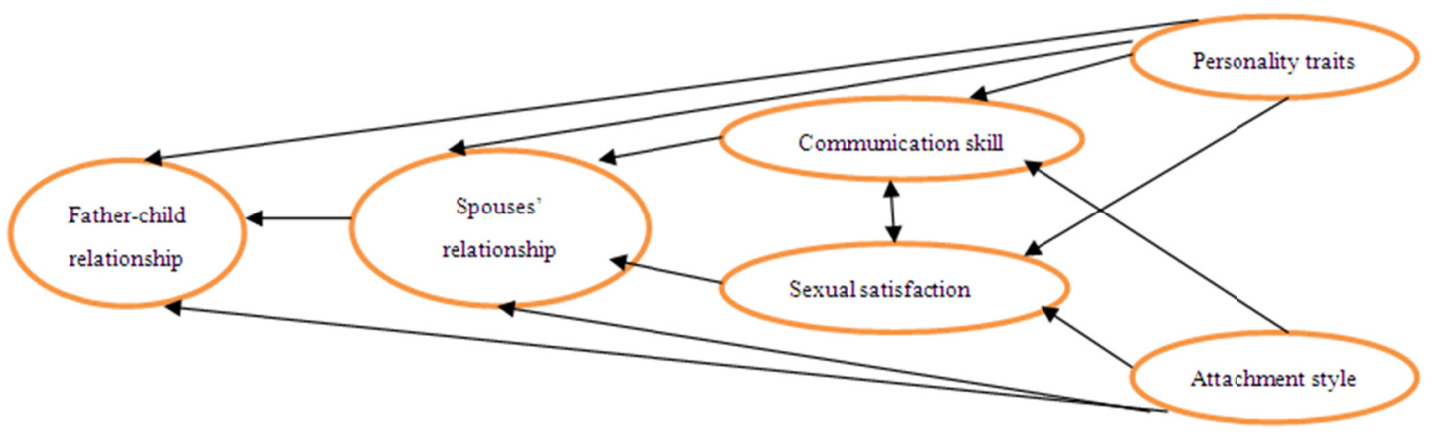

Proposed model about structural relationships among variables

\section{Method}

\subsection{Participants}

Statistical population includes all students of sixth grade boys and girls primary schools of Karaj (24195) with their fathers that parents and children were living together in a family. Since the great number of sub-scales of current research's variables, caused the increase of sample volume according to calculations, therefor according to Raykov and Marconlides (2006), the least sample volume for modeling the structural equations, if the number of calculations based on sub-scales get out of simple situation, must be at least 260 people. Therefor sample of 260 (father and child) was selected and considering stratified sampling, the ration of selected people was in this way that from each region of Karaj Education and training Branch, a girls school and a boys school was randomly selected and from region 1, 37 students (19 girls and 18 boys), from region 2, 63 students (33 girls and 30 boys), from region 3, 80 students ( 40 girls and 40 boys) and from region 4, 80 students ( 40 girls and 40 boys were selected. The distribution of study fathers was based on the number of children ( $6.5 \%$ three children, $77.7 \%$ two children, a little more than $15 \%$ only child, one item five children), duration of marriage (10 to 14 years: $42.3 \%, 15$ to 19 years: $36.5 \%, 20$ to 24 years: $16.9 \%, 25$ to 29 years: $3.8 \%, 30$ to 34 years: $0.4 \%$ ), education level (diploma: $66.9 \%$, associate degree: $10.4 \%$, undergraduate: $20.8 \%$, master degree: $1.9 \%$ ) and level of income (up to 500000 Tomans: $2.3 \%$, from 500000 to 1 million: $42.7 \%, 1$ to 1.5 million: $40.4 \%$, 1.5 to 2 million: $3.5 \%, 2$ millions: $3.5 \%, 2$ million and more: $3.5 \%$ ).

\subsection{Methodology}

The methodology based on goal is developmental and functional. In current plan, analysis of covariance matrix (Structural equation modeling analysis) was used. Sampling was random and stratified.

\subsection{Evaluation Tools}

\subsubsection{Spouses' Communication Pattern Questionnaire (CPQ)}

It is provided by Christensen and Salvi (1991) and discusses three patterns of mutual constructive communication, mutual avoidance communication, mutual demand/withdraw communication in spouses' relationship. Ebadat poor in Iran (2000) in order to estimating the validity of this questionnaire, correlation among scales of this questionnaire and Enrich marital satisfaction questionnaire showed that all scales of this questionnaire have correlation with Enrich marital satisfaction questionnaire. Obtained correlation coefficients for three sub-scales of mutual constructive communication, mutual avoidance communication, and mutual demand/withdraw communication respectively were $0.58,-0.58$ and -0.35 which all of them were meaningful in the level of Alpha 0.01. Ebadat poor (2000) estimated the reliability of this questionnaire's sub-scales by Cronbach's alpha respectively in scales of mutual constructive communication, mutual avoidance 
communication and relationship of female demand/male withdraw, relationship of male demand/female withdraw, and mutual demand/withdraw communication, $0.70,0.71,0.51,0.52,0.66$. The rate of reliability coefficient by Cronbach's alpha was obtained in this study as for mutual constructive communication (0.70), mutual avoidance communication (0.43) and relationship of female demand/male withdraw (0.62) and relationship of male demand/female withdraw (0.52).

\subsubsection{Inventory of Sexual Satisfaction (ISS)}

It has been provided by Larson et al (1998). In Larson study 1998, its scientific validity was confirmed by Harrison and Hudson and its scientific reliability by retest. The rate of reliability correlation of questionnaire was obtained by Cronbach's alpha in this research as for intimacy ( 0.83$)$, the quality of sexual relationships $(0.70)$, sexual orientation (0.78), sexual behavior (0.38) and for sexual satisfaction (0.86).

\subsubsection{Five Factor Personality Inventory (NEO-FFI)}

This scale is a short form of revised questionnaire of NEO-RI-R that is designed for fast evaluation of personality main five factors. This questionnaire has 60 articles that evaluate five aspects of normal personality which are: neuroticism, extroversion, openness to experience, agreeableness and being conscious. Questionnaire reliability was obtained based on Cronbach's alpha coefficient from 0.74 to 0.89 with the mean of 0.81 variable (Kastav McCrae, 1992) and simultaneous validity of questionnaire is reported high with questionnaires of Meyers Brigers, Gilford and Zukerman, personality questionnaire of Minnesota and revised questionnaire of California. The rate of reliability coefficient of questionnaire was obtained by Cronbach's alpha method in this research for neuroticism $(0.75)$, extroversion $(0.68)$, responsibility $(0.80)$, compatibility $(0.71)$ and openness (0.61).

\subsubsection{Attachment Styles of Adults' Questionnaire (ECR-R)}

For evaluating adults' attachment style, revised questionnaire of personal experiences in intimate relationship has been used that Brenan, Ferally and Valero (2000) have developed that that by helping 36 articles in 7 degree scale of Likert evaluates three attachment styles of security, anxious and avoidance. Test reliability in Cronbach's alpha method by Brenan, Ferally and Valero (quoted by Peyvastegar, 2005) for 183 students, is reported for secure attachment style 0.85 , avoidance 0.82 and anxious 0.89 . That represents high reliability. Peyvastegar, 2005 used factor analysis method for calculating the validity of test. The rate of reliability coefficient in this research was obtained for secure attachment style 0.65 , anxious attachment 0.71 and avoidance attachment 0.72 .

\subsubsection{Father-Child Relationship Questionnaire}

The main version of this questionnaire was provided by Fine, Moorland and Shovel in 1983. This scale has sub-scales of positive emotion, cloning and relationship or conversation. Its reliability has good internal consistency with alpha coefficients of 0.61 to 0.94 for factors and general alpha 0.96 (Sanai, 2000) and test validity has good predictor validity and separate children of divorce and integrated from each other (Sanai, 2000). The rate of reliability coefficient by Cronbach's alpha in this study is obtained for positive emotion 0.92 , annoyance / confusion of roles 0.75 , conversation 0.75 , cloning 0.78 and father-child relationship 0.88 .

\subsubsection{Communication Skills Questionnaire}

It was provided by Attarha and Karami in 2010 based on interpersonal model of Hargi and Marshal 1986 and Dickson et al 1993. This test clarifies three factors of excitement management, perception and assertiveness in communication skills. Attarha and Karami did Iranian norm finding of the test by studying 510 high school students of Yazd in educational year of 2005-2006. The reliability of test retest in sub-scale of excitement management was reported 0.88 , in perception 0.79 and in assertiveness 0.70 and the general reliability of test retest 0.90 . Test alpha coefficient also is 0.92 that shows the suitable reliability of test. Criterion validity that includes correlation among criterion and predictors scores of students' compatibility questionnaire that has norm in Iran was used. Observed correlation coefficient between criterion and predictor is 0.43 that is significant in the level of one-thousandth. The rate of reliability coefficient by Cronbach's alpha method in this study was obtained for excitement management 0.67 , others' perception 0.76 , assertiveness 0.79 and communication skills 0.84 .

\section{Results}

After measuring the main constructs, they were tested. Amos software main model output is proposed as following for research hypotheses. 


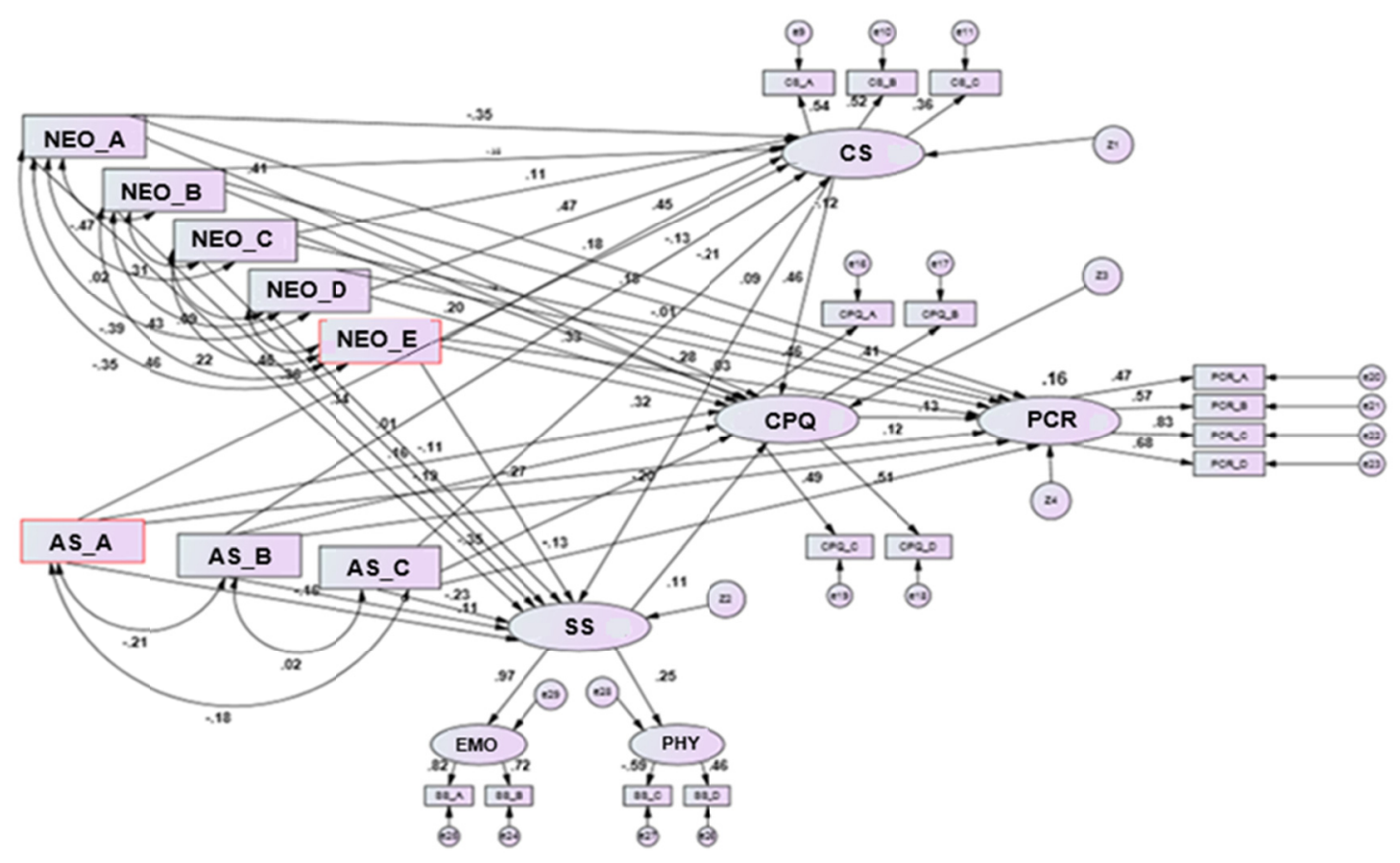

NEO_A: neuroticism, NEO_B: Extraversion, NEO_C: openness to experience, NEO_D: Conscientiousness, NEO_E: Agreeable,

AS_A: secure attachment, AS_B: Anxious attachment, AS_C: avoidant attachment, CS: Communication skill, CS_A: Emotion management, CS_B: Perception of others, CS_C: Self-assertion, SS: Sexual satisfaction, EMO: Emotional, PHY: Physical,

SS_A: Intimacy, SS_B: Quality sexual relations, SS_C: Sexuality tendency, SS_D: Behavior sexual, CPQ: Spouses communication, CPQ_A: constructive communication, CPQ_B: avoidance communication, CPQ_C: demand female / with raw male communication, CPQ_D: demand male / with raw female communication, PCR: Parent-Child Relationship, PCR_A: Positive affection,

PCR_B: Annoyance/confusion, PCR_C: Dialogue, PCR_D: Identification

Figure 1. Constructive equation model is formulated to investigation of the research constructs relations

(Fathers).

Table 1. Indices of model fitness

\begin{tabular}{ccccccc}
\hline \multicolumn{7}{c}{ Indices of Global Model Fitness } \\
\hline Index & CMIN/DF & Df & CFI & PCFI & RMSEA & 0.05 \\
& & & & & & Hoelter \\
\hline Value & 3.826 & 188 & 0.883 & 0.509 & 0.089 & 115 \\
\hline
\end{tabular}

As the data of Table 1 shows, model is fitted suitably. 
Table 2. Standardized Estimation of Direct, Indirect and Total Effects on CPQ and PCR in the Structural Model (Fathers)

\begin{tabular}{lllll}
\hline & \multicolumn{2}{c}{ Effect Types } & & \\
\cline { 1 - 3 } Total effect & Indirect effect & Direct effect & Criterion Variable & Predictor Variable \\
\hline-0.536 & -0.126 & -0.410 & Spouses communication & neuroticism \\
0.310 & 0.124 & 0.186 & Spouses communication & Extraversion \\
0.256 & 0.054 & 0.202 & Spouses communication & openness to experience \\
0.538 & 0.208 & 0.330 & Spouses communication & Agreeableness \\
0.557 & 0.237 & 0.320 & Spouses communication & Conscientiousness \\
0.227 & 0.068 & 0.159 & Spouses communication & secure attachment \\
-0.233 & -0.047 & -0.186 & Spouses communication & Anxious attachment \\
-0.432 & -0.080 & -0.352 & Spouses communication & Avoidant attachment \\
0.107 & - & 0.107 & Spouses communication & Sexual satisfaction \\
0.466 & 0.009 & 0.457 & Spouses communication & Communication skill \\
-0.192 & -0.016 & -0.176 & Parent-Child Relationship & Neuroticism \\
-0.191 & -0.015 & -0.176 & Parent-Child Relationship & Extraversion \\
-0.004 & 0.007 & -0.011 & Parent-Child Relationship & openness to experience \\
0.308 & 0.027 & 0.281 & Parent-Child Relationship & Agreeableness \\
0.064 & 0.032 & 0.032 & Parent-Child Relationship & Conscientiousness \\
0.128 & 0.009 & 0.119 & Parent-Child Relationship & secure attachment \\
-0.209 & -0.006 & -0.203 & Parent-Child Relationship & Anxious attachment \\
-0.138 & -0.010 & -0.128 & Parent-Child Relationship & Avoidant attachment \\
0.014 & 0.014 & - & Parent-Child Relationship & Sexual satisfaction \\
0.060 & 0.060 & - & Parent-Child Relationship & Communication skill \\
\hline$N 0 t e . ~$ & & Constrof of commication & between spouses
\end{tabular}

Note. Based on data in Table 2, the most total effects on construct of communication between spouses is conscientiousness (0.557), agreeableness (0.538), neuroticism (-0.536), communication skills (0.466) and avoidant attachment (-0.432) respectively. Also, most total effects on construct of parent-child relationship is associate to agreeableness (0/308), anxious attachment (-0/209) and neuroticism (-0.192).

Based on the data of Table 2 the most effects of whole on spouse's relationship is respectively related to responsibility $(+0.557)$, compatibility $(+0.538)$, neuroticism $(-0.536)$, communication skills $(+0.466)$ and avoidant attachment $(-0.432)$ while the whole effects of sexual satisfaction, anxious attachment, secure attachment and openness to experience show weaker values. In father-child relationship also the most effects of whole are respectively related to compatibility $(+0.308)$, anxious attachment $(-0.209)$ and neuroticism $(-0.192)$ while communication skills and sexual satisfaction show weaker effects.

\section{Discussion}

Current research followed the discussion of father-child model with mediating the effective relationship of spouses and with investigating attachment style, personal characteristics, communication skills and spouses' sexual satisfaction.

In current research, model general fit goodness measures showed that generally model has had fitness with data and theoretical model was matched with real data. To confirm this result of research, previous researches which investigated designing a model in a field of spousal relationship, can be mentioned. For example Shokrkon, Khojasteh, Attari, Haqiqi, and Shahani (2006) can be mentioned that investigated personality traits, social skills, attachment styles and demographic characteristics as marital relationship's failure and success predictors in divorce demanding couples and normal ones on 61 divorce demanding couples and 100 normal couples with discriminant analysis method and showed that research model has been confirmed and on the other hand 
concluded that by variables of personality traits, social skills, attachment styles and demographic characteristics, failure or success of marital life can be predictable. In Jaberi, Etemadi, Jazayeri, and Ahmad (2014) also with the goal of marital intimacy predicting factors determining, this result was obtained that personality traits, communication skills, attachment styles, communication patterns, conflict solution styles, pathology of relationship with spouse's family and women age are predictor factors of marital intimacy. In current research also, the results of direct and indirect and total in related structural model to fathers' group showed that the most effects of total on structure of spouses' relationship respectively were related to responsibility, compatibility, neuroticism, communication skills and avoidant attachment. For explaining these results it can be said that research shows the existence of relationship among compatibility, responsibility, emotional stability with relationship satisfaction in spouses (Watson \& Hayes, 2004; Bareldez, 2005, Deyrin et al., 2010; Diopter et al., 2012). The result of vertical study on 300 couples and during 50 years showed that the level of neuroticism in both two spouses is a key determiner of marital quality (Rose, 2010; Kelly \& Conley, 1987). Excitability and the lack of stability that can be seen in neurotic people cause being angry and nervous fast in interpersonal interactions and leave negative effect in marital relationships (Mead, 2005). Compatible couples have more positive perceptions from each other that lead to more satisfaction for them (Mead, 2005). Responsible people because of personal commitment, try more objectively for maintaining their marital relationships (Jarvis, 2006) and mange relationships more constructive (Dunellen et al., 2004). Generally each person is equipped with special personality traits and psychological structures for facing their life partner (Kemmelmeier, Danielson, \& Batten, 2005) that is effective with integrating person's perception from his personality and his partner in satisfaction from marital relationship (Fuler, Gomez, \& Grob, 2014). The result of current research also showed the most effects of total on spouses' relationship construct respectively related to responsibility, compatibility and male spouse neuroticism. The result of regression analysis of some researches showed that neuroticism is the first factor (Amiri, Farhoodi, Abdolvand, \& Rezaie-Bidakhavidi, 2011; Donnellane et al., 2004; Caughlin et al., 2000) and compatibility, responsibility, extroversion and openness to experience are respectively factors which predict marital satisfaction (Heaven, Smith, Prabhakar, Abraham, \& Mete, 2006; Watson et al., 2000; Boss, 1991). The other researches' result predicted the first factor as neuroticism and compatibility and the other personality traits as the second one (Botvin, Buss, \& Shackelford, 1997; Tobin, Graziano, Vanman, \& Tassinary, 2000).

The other result of research showed the relationship between spouse's attachment style with spouses' relationship that is aligned with the results of researches (Egeci \& Gencoz, 2011; Finnie, 1999; Keskin, 2008). To confirm this result that among attachment styles, avoidant attachment style of male spouse has shown the most significant relationship in effective spouses' relationship, the research result of Rajaei, Nayeri, and Sedaghati (2000) can be mentioned that in their investigation with checking the relationship among attachment styles with marital satisfaction with choosing 159 married teachers ( 81 women and 78 men) of secondary and high school of Taybad town concluded that the percentage of men was higher than women in a group with avoidant attachment style. To explain this finding it can be said, considering that internal working patterns' process is different between two groups so it seems that there is a difference between two genders in attachment styles as well. The result of Rahimi and Shaker's (2012) research, Sadegh (2007) and Tabe (2006) also showed that men had more scores than women in avoidant attachment style. Generally the less conflict, the more satisfaction and stability and more period of time in romantic relationships will be experiences by secure attached people more that insecure ones (Schmitt, 2005). Insecure attachment style causes that people see their own romantic experiences negatively (Saaverda, Chapman, \& Rogge, 2010) and show destructive patterns from conflict and the lack of negotiation in their conversations (Finnie, Noler, \& Kalan, 1994).

The other results of research showed positive and significant relationship between spouses' communication skills and effective relationship between spouses. To explain this, it can be said that communication skills can help couples in setting an effective, efficient and interactional relationship that is toward their growth and development and decrease the creation of destructive and negative emotions during relationship. Therefor couples who have higher communication skills with strengthening joyful interactions, increase attraction, success and maintaining their relationship.

In this research, a there wasn't a significant relationship between male spouses' sexual satisfaction with effective relationship of spouses. To explain that, it can be said that marital satisfaction and its sub-scales such as sexual satisfaction depend on both people who are in marital relationship and satisfaction or dissatisfaction of women and men is affected from their marital life more than their gender. Therefor the marital structure of current study has been become the creation of this result and other possibility in this field can be because of the lack of men intrinsic tending towards women to reveal marital life realities specially in sexual relationship discussion that has led to this result. 
The results of research related to father-child construct, the most total effects were respectively related to compatibility, anxious attachment and fathers' neuroticism. To explain this result, it can be said that personality determines parents' capacity for kids' improvement and growth in interaction with stresses and environment supportive resources (Belsky, 1984). Parents who show more levels of agreeableness and extroversion and lower levels of neuroticism, have warmer and structured parenting, show more positive interactions, they are enough responsible and an environment where they bring up their children is more structured and stable (Karreman, van Tuijl, Marce, Aken, \& Dekovic, 2008; Smith et al., 2007).

The other result of this research was also that anxious attachment style in father has negative and significant relationship with father's relationship with his child. Researches have shown that people with secure attachment style are warm, responsible and more involved parents (Edward \& Carlson, 1995; Finnie, 2002), while parents with anxious attachment style give contradictory, unreliable and invalid answers to their kids' stresses (Micolencer \& Shiver, 2003) and this causes the weakness of father0child relationship. the researchers of attachment field have shown that parents with insecure attachment style show their emotions less in parenting relationship and show less management and responsibility in facing their kid's negative emotions (Kesidi \& Shiver, 2008) even in compatible structures (Lionetti, 2014; Steele, Hodges, Kaniuk, Steele, Hillman, \& Asquith, 2008) that all of these lead to weakness in relationship of father-child.

\section{Conclusion}

According to current research findings, for promoting the relationship of father-child and parents' education, the family of therapists had better to pay attention to the role of effective factors in spouses' relationships and father-child relationship and based on proposed model in current research, a preventing method can be provided from unsuccessful marriages or revising failures in marital performance and parenting.

\section{Acknowledgements}

It is necessary here to thank all school officials of Karaj and all parents and students who helped us to perform this research.

\section{References}

Amiri, M., Farhoodi, F., Abdolvand, N., \& Rezaie-Bidakhavidi, A. (2011). A study of the relati onship between Big-five personality traits and communication styles with marital satisfaction of married students majoring in public universities of Tehran. Procedi-Social and Behavioral Sciences, 30, 685-689. http://dx.doi.org/10.1016/j.sbspro.2011.10.132

Arefi, M., Mohsen-zadeh, F., Ghezlbashyan, Z., Sadeghpour, A., \& Sheikh-Ismail, D. (2014). Personality similarity, Big Five personality and marital satisfaction. Journal of Counseling \& Family Psychotherapy, 4(3), 551-569.

Attarha, N., \& Karami, A. (2010). Communication skills. Tehran: Psychometrics publication.

Banes, R. (2004). Adult attachment and marital satisfaction: Evidence for dyadic configuration effects. Journal of Social and Personal Relationships, 21(2), 273-282. http://dx.doi.org/10.1177/0265407504041388

Barelds, D. P. H. (2005). Self and partner personality in intimate relationships, European Journal of Personality, 19, 501-518. http://dx.doi.org/10.1002/per.549

Barrientos, J. E. (2006). Psychological variables of sexual satisfaction, Journal of sex of marital therapy, 32, 351-368. http://dx.doi.org /10.1080/00926230600834695

Belsky, J. (1984). The determinants of parenting: A process model.Journal of child Development, 55(1), 83-96. http://dx.doi.org/10.2307/1129836

Bogaerts, S., Dallder, A. L., Knnap, L. M. V., Kunst, M. J. J. M., \& Buschman, J. (2008). Critical incident, adult attachment style, and posttraumatic stress disorder: a comparison of three groups of security workers. Social Behavior and Personality an International, 36(8), 1063-1072. http://dx.doi.org/10.2224/sbp.2008.36.8.1063

Botvin, M. D., Buss, D. M., \& Shackelford, T. K. (1997). Personality \& mate prefrences: Five factor in male selection and martial satisfaction. Journal of personality, 65(1), 107-136. http://dx.doi.org/10.1111/j.1467-6494.1997.tb00531.x

Bowlby, J. (1969). Attachment and loss (Vol. 1: Attachment). New York, NY: Basic Books.

Bowlby, J. (1980). Attachment and loss (Vol. 3: Loss, sadness, and depression). New York, NY: Basic Books.

Bronfen-Brenner, U. (1995). The biological model from a life course perspective: Relations of the participant 
observer. In P. Moen, G. H. Elder Jr., \& K. Luscher (Eds), Examining lives in context (pp. 599-618). Washington, DC: American psychological Association.

Buss, D. M. (1991). Conflict in married couples: personality predictors of Anger and upset. Journal of Personality, 59,663-688. http://dx.doi.org/10.1111/j.1467-6494.1991.tb00926.x

Carnes-Holt, K. (2012). Child-parent relationship therapy for adoptive families. The Family Journal, 20(4), 419-426. http://dx.doi.org/10.1177/1066480712451242

Cassidy, J., \& Shaver, P. R. (2008). Handbook of attachment. Theory, research, and clinical application (2nd ed.). NewYork, NY: Guilford Press.

Casten, K. M. (2004). Marital functioning and communication in a clinical sample of social Anxiety Disorder clients (Doctoral dissertation, Drexel University, Philadelphia, PA. Dissertation Abstracts Intrnational, 65, 1B).

Christensen, A., \& Sullaway, M. (1984). Communication patterns Questionnaire (Unpublished manuscript). University of California, Los angles.

Costa, P. T., \& McCrae, R. R. (1992). Revised NEO personality inventory And NEO five factor inventory. Lutz, Florida: Psychological Asesment Resource, Inc.

Couglin, J. P., Huston, T. L., \& Houts, R. M. (2000). How does personality matter in marriage. An examination of trait anxiety, interpersonal negativity, and marital satisfaction. Journal of Personality \& social Psychology, 78(2), 326-336. http://dx.doi.org/10.1037/0022-3514.78.2.326

Crowleyh, A. K. (2006). The relationship of adult attachment style and interactive conflict styles to marital satisfaction (Doctoral thesis, Texas A \& M University).

Decuyper, M., De Bolle, M., \& De Fruyt, F. (2012). Personality similarity, perceptual accuracy, and relationship satisfaction in dating and married couples. Personal Relationships, 19(1), 128-145. http://dx.doi.org/10.1111/j.1475-6811.2010.01344.x

Donnellane, M. B., Conger, R. D., \& Bryant, C. M. (2004). The big five and Enduring marriage. Journal of Research in Personality, 38, 481-504. http://dx.doi.org /10.1016/j.jrp.2004.01.001

Dyrenforth, P. S., Kashy, D. A., Donnellan, M. B., \& Lucas, R. E. (2010). Predicting relationship and life satisfaction from personality in nationally representative samples from three countries: The relative importance of actor, partner, and similarity effects. Journal of Personality and Social Psychology, 99(4), 690-702. http://dx.doi.org/10.1037/a0020385

Ebadatpour, B. (2008). Normalization gathering in Tehran in 1999-2000 and marital communication patterns. Family Counseling (Master's thesis. Tehran, Tarbiat Moalem University of Tehran).

Egeci, I. S., \& Gencoz, T. (2011). The Effects of Attachment Styles, Problem Solving Skills, and Communication Skills on Relationship Satisfaction. Procida, Social Behavioral Sciences, 30, 2324-2329. http://dx.doi.org/10.1016/j.sbspro.2011.10.453

Engel, G., Olson, K. R., \& Patrick, C. (2002). The personality of love: Fundamental motives and traits related to components of love. Personality \& Individual Differences, 32(5), 839-853. http://dx.doi.org/10.1016/S0191-8869(01)00090-3

Feeney, J. A. (2002). Attachment, marital interaction and relationship satisfaction. Personal Relationship, 13, 19-36. http://dx.doi.org/10.1111/1475-6811.00003

Feeney, J. A., Noller, P., \& Callan, V. J. (1994). Attachment Style, Communication, and satisfaction in the Early Years of Marriage. In K. Bartholomew, \& D. Perlman (Eds.), Advances in personal relationships: Attachment processes in adulthood (Vol. 5, pp. 269-308). London: Jessica Kingsley.

Feeny, J. A. (1999). Adult romantic attachment and couple relationships. In J. Cassidy, \& P. R. Shaver (Eds.). Handbook of attachment theory, research, and clinical applications. London: the Guilford press.

Fine, M. A., Moreland, J. R., \& Schwebel, A. (1983). Long-term effects of divorce on parent-child relationship. Developmental psychology, 19(5), 703-713. http://dx.doi.org/10.1037/0012-1649.19.5.703

Fraley, R. C., \& Shaver P. R. (2000). Adult romantic attachment: Theoretical developments, emerging controversies, and unanswered questions. Review of General Psychology, 4, 132-154. http://dx.doi.org/10.1037/1089-2680.4.2.132

Fraley, R. C., Waller, N. G., \& Brennan, K. A. (2000). An item response theory analysis of self-report measures 
of adult attachment. Journal of Personality and Social Psychology, 78(2), 350-365. http://dx.doi.org/10.1037/0022-3514.78.2.350

Fuler, K., Gomez, V., \& Grob, A. (2014). Personality perceptions and relationship satisfaction in couples. Journal of Research in Personality, 50, 33-41. http://dx.doi.org/10.1016/j.jrp.2014.02.003

Graziano, W. G, Jensen-Campbell, L. A., \& Hair, E. C. (1996). Perceiving interpersonal and reacting to it: The case for agreeableness. Journal of Personality \& Social Psychology, 70(4), 820-835. http://dx.doi.org/10.1037/0022-3514.70.4.820

Greeff, A. P., \& Malherbe, H. L. (2001). Intimacy and marital satisfaction in spouses. Journal of sex \& marital therapy, 27, 247-257. Guilford press. http://dx.doi.org/10.1080/009262301750257100

Gurman, A. S. (2008). Clinical handbook of couple therapy. New York: The Guilford press.

Harvey, D., Weuzel, A., \& Sprecher, S. (2005). The hand book of sexuality in close Relationships. New Jersey.

Heaven, P. C. L., Smith, L. Prabhakar, S. M., Abraham, J., \& Mete, M. E. (2006). Personality and conflict communication patterns in cohabiting couples. Journal of Research in Personality, 40(5), 829-840. http://dx.doi.org/10.1016/j.jrp.2005.09.012

Heavey, C. L., Larson, B. M., Zumtobel, D. C., \& Christensen, A. (1996). The communication patterns questionnaire: The reliability and validity of a constructive communication subscale. Journal of marriage and thefamily, 58, 796-800. http://dx.doi.org/10.2307/353737

Heller, D., Watson, D., \& Hies, R. (2004). The role of person versus situation in life satisfaction: A critical examination. Psychological Bulletin, 130(4), 574-600. http://dx.doi.org/10.1037/0033-2909.130.4.574

Hollist, C. S., \& Miller, R. B. (2005). Perceptions of attachment style and marital quality in midlife marriage.Family Relations, 54, 46-58. http://dx.doi.org/10.1111/j.0197-6664.2005.00005.x

Jakubowski, S. F., Mime, E. P., Brunner, H., \& Mile, R. B. (2004). A review of empirically supported marital $\begin{array}{llll}\text { enrichment } & \text { programs. }\end{array}$ http://dx.doi.org/10.1111/j.0197-6664.2004.00062.x

Jarvis, M. O. (2006). The long term role of newlywed conscientiousness and religiousness in marriage (Unpublished doctoral dissertation). Journal of personality and social psychology, 38, 668-678. Retrieved from http://hdl.handle.net/2152/2542

Ji, J., \& Norling A. M. (2004). Sexual satisfaction of married urban Chinese. Journal of Developing Societies, 20(1-2), 21-38. http://dx.doi.org/10.1177/0169796X04048301

Karahan, T. F. (2007). The effects of a couple's communication program on conflict tendency among married passive couple's educational sciences. Theory \& Practice, 7(2), 845-858.

Kardatzke, K. N. (2009). Perceived Stress, Adult Attachment, Dyadic Coping and Marital Satisfaction of Counseling Graduate Students (Unpublished doctoral dissertation). University of North Carolina.

Kareny, B. P., \& Bradbury, T. N. (2000). Attribution in marriage state or trait? Journal of personality and social psychology, 78(2), 295-309. http://dx.doi.org/10.1037/0022-3514.78.2.295

Karreman, A., van Tuijl, C., Marce, L. A. G., Aken. V.., \& Dekovic, M. (2008). The relation between parental personality and observed parenting: The moderating role of preschoolers' effortful control. Personality and Individual Differences, 44(3), 723-734. http://dx.doi.org/10.1016/j.paid.2007.10.005

Kelly, E. L., \& Conley, J. J. (1987). Personality and compatibility: A prospective analysis of marital stability and marital satisfaction. Journal of Personality and Social Psychology, 52(1), 27-40. http://dx.doi.org/10.1037/0022-3514.52.1.27

Kemmelmeier, M., Danilson, C., \& Batten. J. (2005). What's in a grade? Academic success and political orientation. Personality and social psychology Bulletin, 31(10), 1386-1399. http://dx.doi.org/10.1177/0146167205276085

Keskin, G. (2008). Relationship between mental health, Parental attitude and attachment style in adolescence, Anadolu. Journal of psychiatry, 9(3), 139-147.

Kimberly, R. A., \& Baker, A. T. (2008). Attachment styles, alcohol, and childhood, experiences of abuse: an analysis of physical violence in dating couples. Violence and Victims, 23, 52-65. http://dx.doi.org/10.1891/0886-6708.23.1.52 
Koepke, S., \& Denissen, J. J. A. (2012). Dynamics of identity development and separation-individuation in parent-child relationships during adolescence and emerging adulthood-a conceptual integration. Developmental Review, 32, 67-88. http://dx.doi.org/10.1016/j.dr.2012.01.001

Kurdek, L. A. (1993). Predicting marital dissolution: A 5 year prospective longitudinal study of newlywed couples. Journal of Personality and social psychology, 64(2), 221-242. Retrieved from http://psycnet.apa.org/doi/10.1037/0022-3514.64.2.221

larson, J. H., Anderson, S. M., Holman, T. B., \& Niemann, B. K. (1998). A longitudinal study of the effects of premental communication, relationship stability and self-esteem on sexual satisfaction in the first year of marriage. Journal of sex \& marital therapy, 24(3), 193-206. http://dx.doi.org/10.1080/00926239808404933

Lionetti, F. (2014). What promotes secure attachment in early adoption? The protective roles of infants' temperament and adoptive parents' attachment. Attachment and Human Development, 16, 573-589. http://dx.doi.org/10.1080/14616734.2014.959028

Malouff, J. M., Thorsteinsson, E. B., Schutte, N. S., Bhullar, N., \& Rooke, S. E. (2010). The Five-Factor Model of Personality and relationship satisfaction of intimate Partners: A meta-analysis. Journal of Research in personality, 44(1), 124-127. http://dx.doi.org/10.1016/j.jrp.2009.09.004

Mead, N. (2005). Personality predictors of relationship satisfaction among engaged and married couples. A thesis submitted to the faculty of Brigham young university in partial fulfillment of the requirements for the degree of Master of Science (pp. 1-71). Retrieved from http://lib.byu.edu/about/copyright/

Mikulincer, M., \& Shaver, P. R. (2007). Attachment in Adulthood: Structure, Dynamics, and Change. New York: The Guilford Press.

Milkulincer, M., \& Shaver, P. R. (2003). The attachment behavioral system in adulthood: Activation, psychodynamics, and interpersonal processes. In M. P. Zanna (Ed.), Advances in experimental social psychology (Vol. 35, pp. 53-152). Sandiego: Academic $\quad$ Press. http://dx.doi.org/10.1016/S0065-2601(03)01002-5

Moovahed, M., \& Azizi, T. (2013). Study the relationship between sexual satisfaction and conflicts between spouses. Journal of Women in Development \& Politics (Research of women), 9(2), 191-217.

Nilforooshan, P., Ahmadi, S. A., Fatehizadeh, M., Abedi, M. R., \& Ghasemi, V. (2014). The impact Simultaneous of the general factor personality and dimensions of attachment on the quality of marital relationship. Journal of Counseling \& Family Psychotherapy, 4(3), 473-506.

O'leary, S. G., \& Vidair, H. B. (2005). Marital adjustment, child-rearing disagreement, and over reactive parenting: Predicting child behavior problems. Journal of Family psychology, 19(2), 208-216. http://dx.doi.org/10.1037/0893-3200.19.2.208

Olson, D., Olson, S. A., \& Larson, P. J. (2008). The Couple Checkup. Translation. M. Darini, S. Navabinejad. Tehran: Press Danjeh.

Ozmen, O., \& Gokhon, A. (2010). Attachment styles and marital adjustment of Turkish married individuals. Procedia social and Behavioral siencenes, 5, 367-371. http://dx.doi.org/10.1016/j.sbspro.2010.07.106

Parvin, L., \& John, O. P. (2002). Personality: Theory and Research. Translation: M. J Javadi, P. Kadivar. Tehran: Aeyzh.

Peyvastehgar, M. (2005). Forecast for children with attachment disorder attachment (Doctorate thesis, Faculty of Education and Psychology, Alzahra University).

Rajai, A., Nayrie M., \& Sedaghati, S. H. (2007). Attachment Styles and marital satisfaction. Journal Iranian Psychological, 3(12), 30-47.

Raykov, T., \& Marconlides, G. A. (2006). A first course in structural equation modeling (2nd ed.). Mawwah, N.J.: Erlebaum.

Rholes, W. S., Simpson, J. A., Blakely, B. S., Lanigan, L., \& Allen, E. A. (1997). Adult attachment styles, the desire to have children, and working models of parenthood. Journal of Personality, 65(2), 357-385. http://dx.doi.org/10.1111/j.1467-6494.1997.tb00958.x

Rohner, R. (2007). Handbook for the study of parental acceptance and rejection. USA: Rohner. University of Connecticut, Center for the Study of Parental.

Rose, N. (2010). Neuroticism, Marital Interaction, and Relationship Satisfaction An Exploration of Affect 
Mediation (A thesis submitted to the Faculty of the Graduate School of the University of Colorado in partial fulfillment of the requirements for the degree of Doctor of Phiosophy Department of Psychology).

Runcan, P. L. (2012). The time factor: dose it influence the parent-child relationship? Procedia-social and behavioral sciences, 33, 11-14. http://dx.doi.org/10.1016/j.sbspro.2012.01.073

Runcan, P. L., Constantineanu, C., Iclics, B., \& Popa, D. (2012). The role communication in the parent-child interaction. Procedia. Social and Behavioral sciences, 4. http://dx.doi.org/10.1016/j.sbspro.2012.05.221

Saavedra, M. C., Chapman, K. E., \& Rogge, R. D. (2010). Examining Mechanisms between Attachment and Relationship Quality: Hostile Conflict and Mindfulness as Moderators. Journal of Family Psychology, 24(4), 380-390. http://dx.doi.org/10.1037/a0019872

Saaverda, M. C., Chapman, K. E., \& Rogge, R. D. (2010). Clarifying links between attachment and relationship quality: Hostile Conflict and mindfulness as moderators. Journal of Family psychology, 62, 434-446.

Sadeghi, M. A., Mazaheri, M. A., \& Moutabi, F. (2011). Adult Attachment and Quality of Couples' Communication Based on Observed Couple Interactions. Journal of Psychology, 15(1), 3-22.

Sanaei, B. (2008). Scale of family Assessment. Besat Publication.

Sanford, K. (2010). Assessing conflict communication in couples comparing the validity of self-report, partner-report, and observer ratings. Journal of family psychology, 24(2), 165-174. http://dx.doi.org/10.1037/a0017953

Santayana, G. (2007). Spouse's personality may be hazardous to your health. Weds worth.

Schmitt, D. P. (2005). Is short-term mating the result of insecure attachment? A test of competing evolutionary perspectives. Personality and Social Psychology Bulletin, 31, 747-768. http://dx.doi.org/10.1177/0146167204271843

Shaver, P. R., Hazan, C., \& Bradshaw, D. (1988). Love as attachment: The integration of three behavioral systems. In R. J. Strenberg, \& M. Barnes (Eds.), The Psychology of love (pp.68-99). New Haven, CT: Yale University Press.

Simpson, J. A. (1990). Influence of attachment Styles on romantic relationships. Journal of Personality and Social Psychology, 59(5), 971-980. http://dx.doi.org/10.1037/0022-3514.59.5.971

Smith, C. L., Spinrad, T. L., Eisenberg, N., Payne, T., K., Gaertner, B. M., \& Maxon, E. (2007). Maternal Personality: longitudinal relations to Parenting behavior and maternal emotional Expressions toward

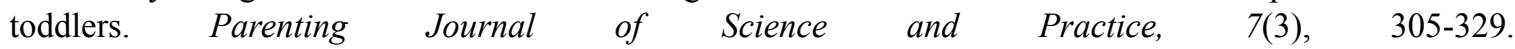
http://dx.doi.org/10.1080/15295190701498710

Sprecher, S., \& McKinney, K. (1993). Sexuality. In A. Weber, \& J. Harvey (Eds.), Perspectives on close relationships (pp. 193-210). http://dx.doi.org/10.4135/9781483326252

Steele, M., Hodges, J., Kaniuk, J., Steele, H., Hillman, S., \& Asquith, K. (2008). Forecasting out comes in previ-ously maltreated children. The use of the AAI in a longitudinal adoption study. In H. Steele, \& M. Steele (Eds.), Clinical applications of the Adult Attachment Interview (pp. 427-451). New York, NY: Guilford Press.

Tabe, J. (2007). The relationship of attachment style method with marital satisfaction (MA thesis in General Psychology, Tehran University).

Tale-Pasand, S., \& Shahbazi, J, G. (2015). Gender Differences in Personality Characteristics of Artistics. Quarterly Journal of Personality \& Individual Differences, 3(6), 113-125.

Taraban, C. B., Hendrick, S. S., \& Hendrick, C. (1998). Loving and liking. In P. A. Andersen, \& L. K. Guerrero (Eds.), Handbook of communication and emotion (pp. 331-351). San Diego: Academic Press.

Tobin, M., Graziano, W. G., Vanman, E. J., \& Tassinary, L. G. (2000). Personality,Emotonal Experience, \& efforts to control emotions. Journal of Personality \& social Psychology, 79(4), 656-669. http://dx.doi.org/10.1037/0022-3514.79.4.656

Walsh, F. (1998). Strengthening family resilience. New York: Guilford Press.

Ward, M. J., \& Carlson, E. A. (1995). Associations among adult attachment representations, maternal sensitivity, and infant-mother attachment in a samle of adolescent mothers. Child development, 66(1), 69-79. http://dx.doi.org/10.1111/j.1467-8624.1995.tb00856.x 
Watson, D., Hubbard, B., \& Wise, D. (2000). General traits of personality and effectivity as predictors of satisfaction in intimate relationships: Evidence from self and partner-ratings. Journal of personality, 68(3), 413-449. http://dx.doi.org/10.1111/1467-6494.00102

Zhang, Q. (2007). Family communication patterns and conflict styles in Chinese parent-child relationships. Communication quarterly, 55, 113-128. http://dx.doi.org/10.1080/01463370600998681

\section{Copyrights}

Copyright for this article is retained by the author(s), with first publication rights granted to the journal.

This is an open-access article distributed under the terms and conditions of the Creative Commons Attribution license (http://creativecommons.org/licenses/by/3.0/). 